\title{
Activity Screening and Structure Modification of Trigonelline as New Anticancer Drug for Non Small Cell Lung Cancer Through In Silico
}

\author{
Kelvin F. Pratama, Muhammad Fauzi, Aliya N. Hasanah* \\ Faculty of Pharmacy, Universitas Padjadjaran, West Java - Indonesia \\ Submitted 31 March 2020; Revised 14 May 2020; Accepted 17 May 2020; Published 30 October 2020 \\ *Corresponding author: aliya.n.hasanah@unpad.ac.id
}

\begin{abstract}
The biggest case of death in 2018 is caused by lung cancer. Non-small cell lung cancer (NSCLC) is most common. One of the cause lung cancer is the over expression of EGFR. Erlotinib is the first line of anticancer for NSCLC with EGFR mutations. However, erlotinib can cause side effects such as liver damage therefore new safe anticancer is needed. Trigonelline is an alkaloid compound from coffee beans that had anticancer activity in pancreatic cancer cells by inhibiting Nrf2 in vitro and in vivo at concentrations of 0.1-1 $\mu \mathrm{M}$. Development of cancer cells by Nrf2 is regulated by EGFR. In this study screening and modification of trigonelline structure was carried out to obtain compounds that have anticancer activity on NSCLC against EGFR computationally. The research procedures carried out are modification of ten trigonelline derived structures, the molecular docking and prediction of physicochemical profiles from trigonelline and its modification also their ADMET. Based on results, KF9 has the lowest free energy of binding which was $-8,88 \mathrm{kcal} / \mathrm{mol}$ and binds to Met 769 which has biological activity with receptor. KF9 has good physiochemical profile and absorption, distribution, also toxicity parameters. KF9 has potential to become a new anticancer drug for NSCLC.

Keywords: Coffee, Drug discovery and Drug development, Molecular structure modification, Nonsmall cell lung cancer, Trigonelline
\end{abstract}

\section{Skrining Aktivitas dan Modifikasi Struktur Trigonelin Sebagai Senyawa Antikanker Paru-Paru Bukan Sel Kecil Baru Secara In Silico}

\begin{abstract}
Abstrak
Kasus kematiaan terbesar tahun 2018 disebabkan oleh kanker paru. Kanker paru karsinoma bukan sel kecil (KPKBSK) adalah kanker yang paling umum terjadi. Salah satu penyebab kanker paru adalah ekspresi yang berlebihan dari EGFR (Epidermal Growth Factor Receptor). Erlotinib adalah lini pertama antikanker untuk KPKBSK dengan mutasi EGFR. Namun, erlotinib dapat menyebabkan efek samping seperti kerusakan hati sehingga diperlukan antikanker baru yang aman. Trigonelin adalah senyawa alkaloid dari biji kopi yang memiliki aktivitas antikanker pada sel kanker pankreas dengan menghambat Nrf2 (Nuclear Factor Erythroid 2-related-factor 2) secara in vitro dan in vivo pada konsentrasi 0,1-1 $\mu \mathrm{M}$. Perkembangan sel kanker oleh Nrf2 ini diketahui diregulasi oleh EGFR. Pada penelitian ini dilakukan skrining dan rekayasa struktur trigonelin untuk mendapatkan senyawa dengan aktivitas antikanker pada KPKBSK terhadap EGFR secara komputasi. Prosedur penelitian yang dilakukan yaitu, memodifikasi sepuluh senyawa turunan trigonelin, penambatan molekul dan prediksi profil fisikokimia dari trigonelin dan modifikasinya, serta prediksi ADMET. Berdasarkan hasil pengujian, senyawa KF9 memiliki energi bebas ikatan terendah dengan energi bebas ikatan - $8,88 \mathrm{kcal} /$ mol dan mengikat residu asam amino Met769 yang memiliki aktivitas biologis dengan reseptor. KF9 memiliki profil fisiokimia, serta parameter absorpsi distribusi, dan toksisitas yang baik. Senyawa KF9 memiliki potensi untuk menjadi obat antikanker baru pada KPKBSK.
\end{abstract}

Kata Kunci: Drug discovery dan Drug development, Kanker paru bukan sel kecil, Kopi, Rekayasa struktur molekul, Trigonelin 


\section{Pendahuluan}

Kanker paru-paru adalah keganasan di organ paru-paru, mencakup keganasan yang berasal dari paru-paru sendiri (primer). Kanker paru primer adalah tumor ganas yang berasal dari epitel bronkus. Kanker paru-paru dibagi menjadi 2 jenis, yaitu kanker paru karsinoma bukan sel kecil (KPKBSK) dan kanker paru karsinoma sel kecil (KPKSK). Sekitar 85\% individu didiagnosis menderita jenis kanker paru bukan sel kecil. Kanker ini meliputi karsinoma sel skuamosa, adenokarsinoma dan karsinoma sel besar. Berbeda dengan kanker paru karsinoma bukan sel kecil, jenis kanker paru karsinoma sel kecil (KPKSK) dibagi menjadi dua kelompok, yaitu stadium terbatas dan lanjut. Penyebab utama kanker paru-paru adalah kebiasaan merokok. ${ }^{1}$

Berdasarkan data dari GLOBOCAN pada tahun 2018, kanker paru-paru menduduki urutan pertama sebagai kasus kanker dengan angka kejadian dan penyebab kematian paling tinggi di dunia. Persentase untuk kanker paru-paru berdasarkan kasus kejadian sebesar 11,6\% dari 2.094.000 kasus baru yang ada dan perkiraan angka kematian disebabkan oleh kanker paru-paru adalah $18,4 \%$ dari 1.800 .000 kasus kanker penyebab kematian. Di Indonesia, kasus kanker paruparu terhitung sebanyak 30.023 kasus dan menempati urutan ketiga dengan jumlah kasus kanker terbanyak setelah kanker payudara dan serviks pada tahun $2018 .^{2}$

Salah satu pengobatan KPKBSK adalah kemoterapi. Erlotinib adalah lini pertama antikanker untuk KPKBSK dengan mutasi EGFR. $^{3}$ Erlotinib adalah obat digunakan untuk terapi KPKBSK, kanker pankreas dan beberapa jenis kanker lain. Mekanisme kerja erlotinib sebagai antikanker yaitu dengan menghambat reaksi fosforilasi intraseluler pada EGFR tirosin kinase. ${ }^{4}$ Akan tetapi, saat ini dosis efektif minimal pada erlotinib belum ditentukan pada pasien dengan mutasi EGFR. ${ }^{5}$ Penggunaan erlotinib juga dapat menimbulkan efek samping yang cukup serius berupa kerusakan hati dan terbentuknya lesi pada sistem pencernaan. ${ }^{6}$ Oleh karena itu, masih diperlukan obat antikanker lain yang memiliki efek samping yang rendah dan aman bagi pasien. Pemanfaatan sumber daya alam yang ada di Indonesia seperti tanaman kopi yang dapat dikaji dan teliti sebagai tanaman yang menyediakan senyawa untuk penemuan dan pengembangan obat baru khususnya untuk KPKBSK. Selain itu, senyawa yang berasal dari bahan alam diklaim memiliki efek samping yang lebih rendah.?

Trigonelin merupakan senyawa bahan alam termasuk golongan alkaloid dalam biji kopi yang berfungsi untuk menghasilkan senyawa aroma dalam kopi. Trigonelin telah diketahui memiliki aktivitas melindungi hati dan ginjal, antikanker, antioksidan, antihipertensi, hipolipidemia, antidiabetes, dan neuroprotektif. ${ }^{8}$ Penelitian mengenai senyawa trigonelin di dalam biji kopi masih jarang ditemukan karena kandungan trigonelin di dalam kopi yang hanya sekitar $0,3 \%-1,3 \%$. Salah satu penelitian menyebutkan bahwa trigonelin secara efisien menghambat aktivitas Nrf2 (Nuclear Factor Erythroid 2-related factor 2) pada sel kanker pankreas secara in vitro dan in vivo pada konsentrasi $0,1-1 \mu \mathrm{M} .^{10}$ Jalur persinyalan Nrf2 diketahui berhubungan dekat dengan EGFR dalam perkembangan sel kanker. Peningkatan aktivitas Nrf2 diketahui diregulasi oleh EGFR. ${ }^{11}$ EGFR berperan dalam proses aktiviasi, regulasi, dan stabilitas protein $\mathrm{Nrf} 2 .{ }^{12}$

Saat ini masih belum ada penelitian yang meneliti aktivitas antikanker trigonelin terhadap EGFR khususnya penyakit KPKBSK. Pemanfaatan senyawa trigonelin sebagai antikanker pada kanker paru-paru dapat memberikan inovasi baru dalam pengobatan kanker saat ini. Penelitian ini bertujuan untuk mendapatkan derivat senyawa trigonelin baru yang memiliki aktivitas sebagai antikanker lebih baik dan toksisitas yang rendah untuk KPKBSK. Berdasarkan potensi senyawa trigonelin untuk menjadi obat antikanker baru maka perlu dilakukan skrining aktivitas dan rekayasa struktur trigonelin untuk mendapatkan senyawa yang memiliki aktivitas sebagai antikanker paruparu dengan cara menginhibisi EGFR melalui kimia komputasi. Metode kimia komputasi yang dilakukan pada penelitian ini terdiri dari modifikasi struktur senyawa trigonelin, 
penambatan molekul, prediksi profil fisikokimia dari trigonelin dan modifikasinya, serta prediksi ADMET.

\section{Metode}

\subsection{Alat}

Simulasipenambatanmolekuldilakukan menggunakan seperangkat komputer HP dengan spesifikasi Intel(R) Cori(TM) i5, CPU@1.80 GHz, RAM (Random Acces Memory) 4.00 GB dan sistem Operasi Windows 10 Enterprise. Pro 64-bit, x64 based processor, dilengkapi dengan program MGLTools terdiri dari aplikasi Autodocks (The Scripps Research Institute, Inc.), ChemDraw Ultra 12.0, Discovery Studio2016 Client ${ }^{\circledR}$ dan PreADMET software.

\subsection{Bahan}

Senyawa uji yang digunakan adalah erlotinib yaitu obat antikanker pada KPKBSK sebagai senyawa uji alami reseptor EGFR tirosin kinase dan obat pembanding, senyawa trigonelin dan turunan senyawa trigonelin hasil modifikasi. Data struktur 3D kristal reseptor yang digunakan untuk analisis penambatan molekul diperoleh dari Protein Data Bank (PDB) dengan situs (http://www. rcsb.org/pdb/). Reseptor yang digunakan untuk memprediksi aktivitas sebagai antikanker KPKBSK yaitu reseptor EGFR tirosin kinase kode PDB:4HJO.

\subsection{Prosedur}

\subsubsection{Preparasi Reseptor}

Reseptor yang digunakan adalah reseptor EGFR tirosin kinase kode PDB $4 \mathrm{HJO}$, reseptor ini merupakan reseptor kanker serviks yang di download pada situs Protein Data Bank (http://www.rscb.org/pdb). Reseptor divisualisasi menggunakan program Discovery Studio 2016 Client ${ }^{\circledR}$ dengan menghilangkan molekul air dan senyawa uji alaminya. Hasilnya berupa reseptor murni yang dapat dilihat pada gambar 1, kemudian disimpan dengan format Protein Data Bank (.pdb).

\subsubsection{Preparasi Senyawa Uji dan Modifikasi} Struktur Trigonelin

Dalam preparasi senyawa uji dan modifikasi struktur senyawa uji dilakukan dengan cara memiripkan senyawa uji dengan senyawa pembanding, perpanjangan, subtitusi dan penambahan gugus tertentu. Pembuatan struktur trigonelin bentuk 2D beserta modifikasinya dilakukan menggunakan aplikasi ChemDraw Ultra 12.0. Struktur 2D tersebut kemudian dioptimasi menjadi struktur 3D menggunakan Chem3D Ultra 12.0 dan dilakukan minimalisasi energi semi empiris agar diperoleh geometri dan konformasi struktur ligan yang tepat.

\subsubsection{Validasi Metode Penambatan Molekul}

Pada validasi metode penambatan molekul senyawa uji (ligand) yang digunakan adalah senyawa alami bawaan dari reseptor/ protein (native ligand) yang di tambatkan kembali ke reseptor. Nilai yang dilihat adalah Root Mean Square Deviation (RMSD).

\subsubsection{Penambatan Senyawa Uji dengan \\ Reseptor \\ Penambatan molekul dilakukan} menggunakan perangkat lunak autodock ${ }^{4}$.

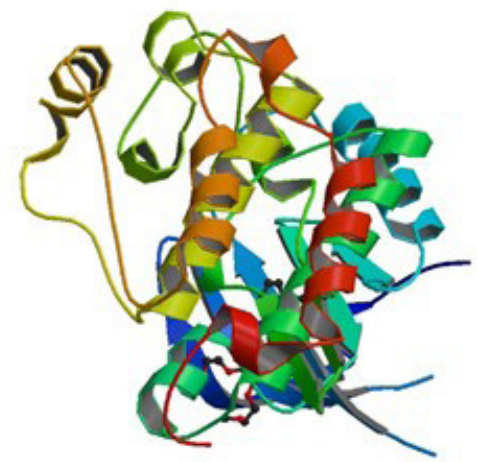

Gambar 1. Visualisasi reseptor (4HJO) menggunakan program Discovery Studio 2016 Client $\AA$ 
(run-autodock) dengan menambatkan antara senyawa uji dan reseptor, kemudian diedit cmd file dengan menghapus alamat directory kerja sehingga pada kolom cmd berisi (D:/ Autodock/autodock4 -p dock.dpf -1 dock.dlg \&) kemudian klik launch.

\subsubsection{Visualisasi Interaksi Ligan dengan \\ Reseptor}

Hasil kalkulasi penambatan molekul dilihat pada output dalam format notepad. Penentuan konformasi senyawa uji hasil penambatan molekul dilakukan dengan memilih konfigurasi senyawa uji yang memiliki energi bebas ikatan yang paling rendah (pose terbaik). Posisi dan orientasi senyawa uji tersebut pada makromolekul, serta asam-asam amino yang terikat pada senyawa uji divisualisasi dengan program Discovery Studio2016 Client ${ }^{\circledR}$ untuk melihat kecocokan bentuk dan situs tambatnya dalam bentuk modeling 3D-farmakofor.

\subsubsection{Prediksi Profil Fisikokimia dengan ChemOffice}

Parameter fisikokimia dihitung menggunakan program ChemOffice. Hasil dari pembuatan struktur trigonelin bentuk 2D beserta modifikasinya dilakukan menggunakan aplikasi ChemDraw Ultra 12.0. Program secara otomatis menghitung nilai prediksi dari parameter-parameter fisikokimia, yaitu : berat molekul, LogP, jumlah ikatan donor dan akseptor hidrogen (show chemical properties windows).

\subsubsection{Prediksi Profil Farmakokinetik dan}

Toksisitas dengan PreADMET

Parameter ADMET dihitung menggunakan program preADMET ${ }^{\circledR}$ yang diakses melalui situs (https://preadmet. bmdrc.kr/adme/). Struktur kimia dari senyawa digambar atau diunggah dalam format Mol file (.mol). Program secara otomatis menghitung nilai prediksi dari parameter-parameter yang dipilih, yaitu: Human Intestinal Absorption (HIA), permeabilitas terhadap sel Human colon adenocarcinoma (Caco-2), Plasma Protein Binding (PPB) serta sifat karsinogenik dan mutagenik.

\section{Hasil}

Modifikasi struktur trigonelin dengan pendekatan bioisosterisme didapatkan 10 modifikasi senyawa trigonelin. Struktur senyawa trigonelin dan modifikasinya dapat dilihat pada Tabel 1.

Validasi metode penambatan molekul dilakukan untuk memvalidasi parameter penambatan molekul yang akan digunakan dalam skrining senyawa trigonelin. Posisi penambatan molekul pada senyawa dipilih berdasarkan bentuk interaksi antarmolekul yang terjadi pada senyawa uji dengan reseptor dan energi bebas ikatan terendah. Berdasarkan hasil tumpang tindih antara senyawa uji alami (native ligand) dan senyawa uji pada penambatan ulang didapatkan nilai RMSD $0,91 \AA$.

Penentuan tata letak kotak melibatkan pengaturan parameter dan penentuan grid box. Pada reseptor $4 \mathrm{HJO}$, hasil grid box sebagai sisi aktif memiliki koordinat: pusat $\mathrm{x}$ $=24.407, \mathrm{y}=9.151 \mathrm{z}=-0.636$ dengan jarak $0,375 \AA$ A. Persiapan reseptor $4 \mathrm{HJO}$ dengan Autodock 4.2 dan visualisasi reseptor (4HJO) dengan hasil penambatan molekul ulang dapat dilihat pada Gambar 2.

Penambatan senyawa trigonelin dan modifikasinya ke reseptor dilakukan untuk mendapatkan energi bebas ikatan yang terendah dengan reseptor. Hasil penelitian menunjukkan bahwa senyawa KF9 menghasilkan energi bebas ikatan terendah dengan nilai $-8,88 \mathrm{kkal} / \mathrm{mol}$ dibandingkan dengan erlotinib $-8,48 \mathrm{kkal} / \mathrm{mol}$. Hasil simulasi penambatan molekul erlotinib dan trigonelin beserta modifikasi strukturnya terhadap reseptor EGFR tirosin kinase (4HJO) dapat dilihat pada Tabel 2. KF9 mengikat residu asam amino berupa Gln767, Met769, Lys704, Lys692, dan Lys704. Visualisasi hasil penambatan molekul senyawa KF9 dengan reseptor dapat dilihat pada Gambar 3.

Senyawa trigonelin dan modifikasinya memiliki profil fisikokimia yang baik berdasarkan prediksi Lipinski's Rule Of Five. Hasil prediksi Lipinski's Rule Of Five senyawa trigonelin dan modifikasinya dapat dilihat pada Tabel 3. Senyawa KF9 memiliki nilai HIA, permeabilitas terhadap sel Caco- 
Tabel 1. Gambar senyawa trigonelin dan modifikasinya

\begin{tabular}{|c|c|c|}
\hline No & Nama Molekul & Modifikasi Struktur Trigonelin \\
\hline 1 & Trigonelin & \\
\hline 2 & KF1 & \\
\hline 3 & KF2 & $\mathrm{CH}_{3}$ \\
\hline 4 & KF3 & \\
\hline 5 & KF4 & \\
\hline 6 & KF5 & \\
\hline 7 & KF6 & \\
\hline 8 & KF7 & \\
\hline 9 & KF8 & \\
\hline 10 & KF9 & \\
\hline 11 & KF10 & \\
\hline
\end{tabular}




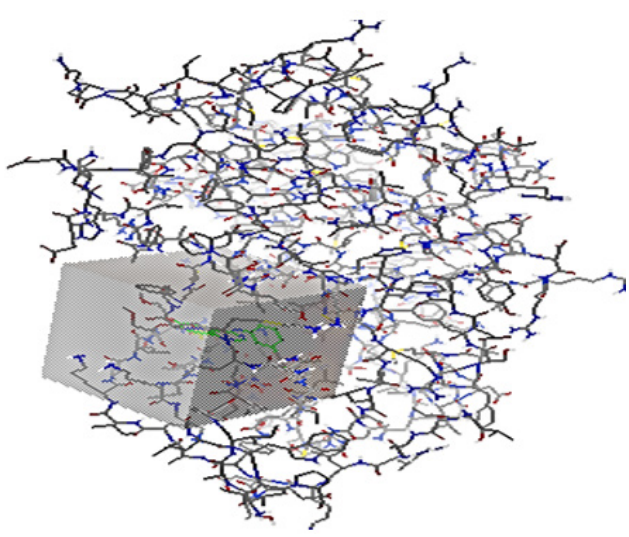

A

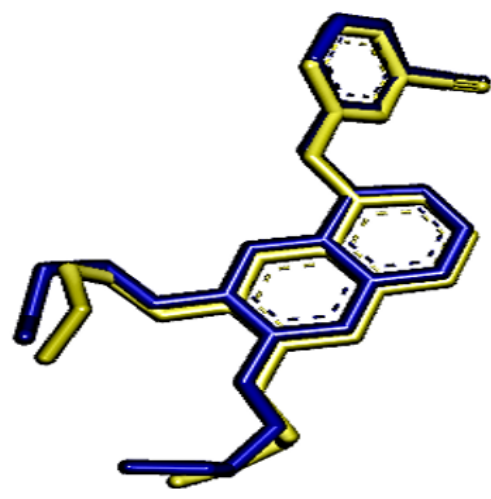

B

Gambar 2. (A) Persiapan reseptor (4HJO) dengan Autodock 4.2 (B) Visualisasi reseptor (4HJO) tumpang tindih senyawa uji alami (biru) dengan hasil penambatan molekul ulang (kuning)

2, PPB yang baik serta bersifat mutagenik dan non-karsinogenik. Nilai HIA, sel Caco2, PPB dan toksisitas senyawa trigonelin dan modifikasinya dapat dilihat pada Tabel 4.

\section{Pembahasan}

Dalam persiapan senyawa uji dan modifikasi dibuat sepuluh senyawa desain trigonelin (Senyawa KF1 sampai KF10) yang difokuskan pada gugus amina atau N-metilpiridinium (Tabel 1). Modifikasi dilakukan karena senyawa trigonelin mudah terdegradasi hingga $60-90 \%$ karena perubahan suhu. $^{13}$ Modifikasi senyawa trigonelin menggunakan pendekatan bioisosterisme berupa merancang obat baru menggunakan perancangan secara rasional dengan memodifikasi senyawa pemandu. ${ }^{14}$ Pendekatan bioisosterisme dalam modifikasi senyawa trigonelin bertujuan untuk meningkatkan kelarutan senyawa dan aktivitas farmakologi serta memperbaiki selektifitas terhadap reseptor.

Penambatan molekul senyawa trigonelin menggunakan struktur kristal 3D makromolekul yaitu reseptor EGFR tirosin kinase yang diunduh dari Protein Data Bank (PDB) melalui website (https://www.rcsb. org/) dengan PDB ID: 4HJO dengan nilai resolusi sebesar 2,75 A. Dalam skrining senyawa trigonelin perlu dilakukan modifikasi struktur guna memperoleh senyawa uji yang memiliki energi bebas ikatan dan nilai kesesuaian yang tinggi dengan sisi reseptor sel kanker.

Analisis yang digunakan untuk mengevaluasi hasil validasi penambatan molekul adalah nilai RMSD, situs pengikatan dan parameter yang digunakan. Analisis dianggap valid jika hasil yang diperoleh RMSD $\leq 2 \AA .15$ Berdasarkan hasil validasi diperoleh nilai RMSD sebesar $0,91 \AA$, nilai RMSD memenuhi persyaratan validasi sehingga parameter dapat digunakan untuk

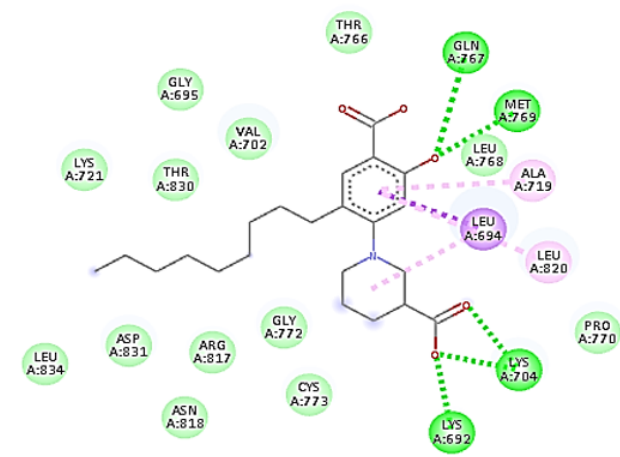

A

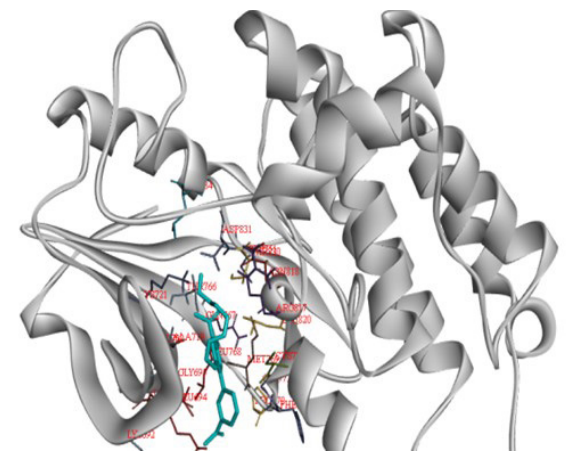

B

Gambar 3. Visualisasi reseptor (4HJO) menggunakan program Discovery Studio 2016 Client $\mathbb{R}$ 
Tabel 3. Hasil Prediksi Lipinski's Rule Of Five

\begin{tabular}{cccccc}
\hline \multirow{2}{*}{ No } & Nama Molekul & Berat Molekul & Log P & \multicolumn{2}{c}{ Ikatan Hidrogen } \\
\cline { 5 - 6 } & & & & Donor & Akseptor \\
\hline 1 & Erlotinib & 393,43 & 3,12 & 1 & 7 \\
3 & Trigonelin & 137,14 & $-4,14$ & 0 & 3 \\
4 & KF1 & 400,40 & $-1,72$ & 0 & 10 \\
5 & KF2 & 165,18 & $-3,26$ & 0 & 3 \\
6 & KF3 & 171,58 & $-3,53$ & 0 & 4 \\
7 & KF4 & 227,68 & $-2,45$ & 0 & 4 \\
8 & KF5 & 241,71 & $-2,01$ & 0 & 4 \\
9 & KF6 & 239,47 & $-1,01$ & 2 & 1 \\
10 & KF7 & 287,26 & $-2,38$ & 6 & 0 \\
11 & KF8 & 259,21 & 0,15 & 2 & 7 \\
12 & KF9 & 385,45 & 4,22 & 2 & 8 \\
\hline
\end{tabular}

simulasi penambatan molekul. Analisis hasil penambatan molekul dinilai pada nilai energi bebas ikatan dan berapa banyak interaksi antara asam amino senyawa uji dengan protein reseptor.

Hasil pengujian didapatkan senyawa KF9 yang memiliki nilai energi bebas ikatan terendah sebesar $-8,88 \mathrm{kkal} / \mathrm{mol}$ dibandingkan dengan erlotinib $-8,48 \mathrm{kkal} / \mathrm{mol}$ dan struktur modifikasi lainnya. Struktur KF9 dimodifikasi dengan menambahkan struktur asam 5-nonil2,4-dihidroksibenzoat. Jenis ikatan dan jumlah ikatan pada KF9 dan erlotinib terdapat perbedaan, dimana terbentuk lebih banyak ikatan hidrogen antara KF9 dengan reseptor jika dibandingkan dengan erlotinib. KF9 memiliki 2 ikatan hidrogen dengan reseptor pada gugus hidroksil dari struktur 5-nonil2,4-dihidroksibenzoat dan 3 ikatan hidrogen pada gugus karboksilat pada struktur alami trigonelin (Gambar 3). Akan tetapi erlotinib hanya memiliki 3 ikatan hidrogen. Hal tersebut membuat KF9 memiliki energi bebas ikatan yang lebih rendah (Tabel 2). Semakin kecil atau negatif nilai energi bebas ikatan menunjukkan ikatan yang kuat dengan reseptor. ${ }^{15}$

Selain itu ditinjau dari ikatannya dengan asam amino, senyawa KF8 dan KF9 mengikat lebih banyak asam amino dari senyawa uji alami (native ligand) ke reseptor yaitu 5 residu asam amino dengan berikatan hidrogen. Hasil penambatan molekul menunjukkan bahwa residu Met769 memainkan peran penting dalam pembuatan ikatan hidrogen dengan EGFR. ${ }^{16}$ Met769 juga diketahui sebagai residu utama dalam pengikatan inhibitor potensial. ${ }^{17}$ Dimana dalam interaksi ini asam amino Met769 adalah residu asam amino yang menyediakan aktivitas yang memungkinkan senyawa KF9 dengan senyawa uji alami yang memiliki aktivitas biologis dengan reseptor pada sisi aktif. KF9 membentuk ikatan hidrogen dengan NH backbone dari Met769 di region hinge. Amida backbone dari Met769 juga mendonorkan ikatan hidrogen ke N1 dari bagian erlotinib. Ikatan hidrogen kunci tipe NH---N dari Met769 adalah interaksi kinase-inhibitor yang paling umum. ${ }^{18}$ Dibandingkan dengan erlotinib, KF9 secara tepat masuk ke dalam kantung pengikat ATP dalam struktur kristal EGFR, menunjukkan bahwa KF9 mungkin merupakan inhibitor EGFR yang potensial. Selain itu penelitian dari Sugunakala dan Selvaraj. menunjukkan keberadaan ikatan hidrogen antara protein asam amino target Met793 bertanggung jawab untuk aktivitas katalitik domain pada EGFR. ${ }^{19}$

Lipinski's Rule of Five adalah aturan praktis untuk mengevaluasi sifat fisikokimia senyawa yang akan diberikan secara oral.20 
Tabel 3. Prediksi absorpsi, distribusi, dan toksisitas

\begin{tabular}{ccccccc}
\hline \multirow{2}{*}{ No } & \multirow{2}{*}{ Nama Senyawa } & \multicolumn{2}{c}{ Absorpsi } & Distribusi & \multicolumn{2}{c}{ Toksisitas } \\
\cline { 3 - 7 } & & HIA $(\%)$ & Caco2 & PPB & Mutagenik & Karsinogenik \\
\hline 1. & Erlotinib & 96,28 & 54,87 & 93,00 & + & - \\
2. & Trigonelin & 95,13 & 21,08 & 0,00 & + & - \\
3. & KF1 & 98,07 & 34,52 & 38,49 & + & - \\
4. & KF2 & 96,55 & 21,73 & 7,78 & + & - \\
5. & KF3 & 97,72 & 21,11 & 0,00 & + & - \\
6. & KF4 & 98,21 & 21,40 & 14,57 & + & - \\
7. & KF5 & 98,19 & 22,24 & 21,97 & + & - \\
8. & KF6 & 96,08 & 50,66 & 44,54 & + & - \\
9. & KF7 & 97,74 & 21,57 & 90,12 & + & - \\
10. & KF8 & 86,18 & 20,57 & 45,75 & + & - \\
11. & KF9 & 94,07 & 21,01 & 90,11 & + & - \\
12. & KF10 & 97,55 & 21,04 & 93,03 & + & - \\
\hline
\end{tabular}

Aturan ini menggambarkan sifat fisikokimia dalam fase farmakokinetik dalam tubuh manusia, termasuk penyerapan, distribusi, metabolisme, dan ekskresi. Oleh karena itu, dalam mendesain obat yang akan diberikan secara oral diharapkan memenuhi Lipinski's Rule of Five, yaitu:

1.Tidak lebih dari 5 donor ikatan hidrogen,

2.Tidak lebih dari 10 akseptor ikatan hidrogen,

3.Massa molekul kurang dari 500 dalton,

4. Nilai $\log$ P tidak lebih dari $5 .{ }^{20}$

Berdasarkan aturan ini maka hasil semua senyawa memenuhi Lipinski's Rule Of Five. Jika memenuhi sekitar 90\% persyaratan di atas maka didefinisikan suatu senyawa memiliki kelarutan, permeabilitas, dan bioavaibilitas yang lebih baik. ${ }^{21}$ Erlotinib dan semua senyawa modifikasi trigonelin memiliki profil fisikokimia yang baik karena memenuhi Lipinski's Rule of Five (Tabel 3). Senyawa hasil modifikasi KF9 yang memiliki energi bebas ikatan terendah dengan reseptor dapat dijadikan sediaan padat yang diberikan secara rute oral. Hal ini dikarenakan senyawa KF9 memenuhi Lipinski's Rule of Five sehingga memiliki bioavaibilitas yang baik.
Absorpsi, distribusi, dan toksisitas menjadi hal yang sangat penting dalam bidang farmasi untuk menilai suatu kandidat obat di dalam tubuh. Parameter absorpsi terdiri dari nilai HIA (Human Intestinal Absorption) dan permeabilitas terhadap sel Caco-2 serta parameter distribusi yaitu PPB (Protein Plasma Binding) serta parameter toksisitas terdiri dari sifat karsinogenik dan mutagenik (Tabel 4). Human Intestinal Absorption (HIA) menunjukkan penyerapan obat oleh usus manusia. Nilai HIA 0-20\% menunjukkan senyawa yang diserap dengan buruk, nilai HIA 20-70\% menunjukkan senyawa yang terserap cukup, dan nilai HIA $70-100 \%$ menunjukkan senyawa terserap dengan baik. ${ }^{22}$ Nilai HIA KF9 adalah 94,07\% sedangkan erlotinib memiliki nilai HIA sebesar 96,28\%. Hal ini menunjukkan bahwa tidak terdapat perbedaan yang signifikan nilai HIA erlotinib dengan KF9 karena dapat diserap dengan baik oleh usus.

Nilai PCaco-2 kurang dari 4 menunjukkan rendahnya permeabilitas obat, nilai 4-70 menunjukkan permeabilitas yang sedang, dan nilai PCaco2 lebih dari 70 menunjukkan permeabilitas yang tinggi. ${ }^{23}$ Nilai Caco-2 KF9 adalah 21,01 sedangkan erlotinib sebesar 54,87 menunjukkan bahwa obat ini memiiki kemampuan menembus membran sel yang sedang. 
Nilai PPB lebih dari 90\% menunjukkan ikatan protein yang kuat sedangkan nilai kurang dari 90\% menunjukkan ikatan protein yang lemah. ${ }^{22}$ Nilai PPB KF9 adalah $90.11 \%$ sedangkan erlotinib bernilai 93,00\%. Hal ini menunjukkan bahwa senyawa erlotinib berikatan kuat dengan protein dibandingkan dengan KF9 sehingga erlotinib akan membutuhkan waktu yang lama untuk mencapai reseptor. Erlotinib terikat 93\% pada protein albumin dan alpha-1 acid glycoprotein (AAG). ${ }^{3}$ Hanya obat yang tidak terikat pada protein plasma dapat berdifusi atau melintasi membran sel dan mengikat target farmakologis. Akibatnya, tingkat pengikatan obat dengan protein plasma tidak hanya memengaruhi profil farmakokinetik obat tetapi juga profil farmakodinamik. ${ }^{22}$

Toksisitas erlotinib, trigonelin, dan senyawa modifikasinya diuji dengan uji Ames untuk mengetahui sifat mutagenesitas dan uji karsinogenesitas menggunakan metode in vivo pada tikus yang diprediksi dengan PreADMET. Uji Ames merupakan uji biologis yang memanfaatkan bakteri untuk menilai potensi mutagenik suatu senyawa kimia. ${ }^{24}$ Berdasarkan uji Ames, erlotinib, trigonelin, dan senyawa modifikasi bersifat mutagen yang menunjukkan bahwa senyawa-senyawa tersebut dapat menyebabkan perubahan secara permanen pada gen tetapi tidak berpotensi menyebabkan kanker atau tidak bersifat karsinogenik. Hubungan mutagenesitas dan karsinogenesitas adalah mutasi terjadi hanya pada organ yang berpotensi menjadi kanker. ${ }^{25}$

\section{Simpulan}

Senyawa modifikasi trigonelin yaitu KF9 memiliki ikatan pada reseptor paling kuat dibandingkan dengan erlotinib dan senyawa modifikasi lain dengan energi bebas ikatan sebesar $-8,88 \mathrm{kcal} / \mathrm{mol}$ dan mengikat 5 residu asam amino reseptor berupa $\mathrm{G} \ln 767$, Met769, Lys704, Ly692, dan Lys704 dengan berikatan hidrogen. Met769 adalah residu asam amino utama yang memberikan aktivitas farmakologis dengan interaksi EGFR kinase-inhibitor. Senyawa trigonelin dan modifikasinya memiliki sifat fisikokimia yang baik yang memenuhi Lipinski's Rule Of
Five sehingga memiliki bioavaibilitas yang baik. Senyawa KF9 memiliki profil absorpsi yang baik dengan nilai HIA sebesar 94.07\% dan sel Caco-22 21,01 serta profil distribusi yang baik dengan nilai PPB sebesar 90,11\%. Senyawa KF9 tidak berifat karsinogenik dan bersifat mutagenik. Senyawa KF9 memiliki potensi untuk menjadi obat antikanker baru pada KPKBSK.

\section{Daftar Pustaka}

1. Kemenkes RI. Pedoman Nasional Pelayanan Kedokteran : Kanker Paru. Jakarta : Komite Penanggulangan Kanker Nasional; 2017.

2. Global Cancer Observatory. Precentages of new cancer cases and cancer deaths worldwide in 2018. [Diunduh pada 15 Maret 2020]. Tersedia dari: https://gco. iarc.fr/

3. Drugbank. Erlotinib Drug. [Diakses pada Tanggal 1 Maret 2020]. Tersedia dari: https://www.drugbank.ca/drugs/ DB00530.

4. Gridelli C, De MF, Di MM, Cortinovis D, Cappuzzo F, Mok T. Gefitinib as first line treatment for patients with advanced nonsmall-cell lung cancer with activating epidermal growth factor receptor mutation: Review of the evidence. Journal of Lung Cancer. 2012;71(3):249-57.

5. Becker AMD, Van WA, Smitt EF, Postmus PE. Side-Effects of Long-Term Administration of Erlotinib in Patients with Non-small Cell Lung Cancer. Anticancer Res. 2010;30(4):1301-10.

6. Cancer Research UK. Side Effects of Erlotinib (Tarceva). [Diakses pada 1 Maret 2020]. Tersedia dari : https:// www.cancerresearchuk.org/about-cancer/ cancer-in $\% 20$ general/treatment/cancerdrugs/drugs/erlotinib/side-effects

7. Wink M. Modes of Action of Herbal Medicines and Plant Secondary Metabolites. Medicines. 2015;2(3)251286.

8. Mohamadi N, Sharififar F, Pournamdari M, Ansari M. A Review on Biosynthesis, Analytical Techniques, and Pharmacological Activities of 
Trigonelline as a Plant Alkaloid. Journal of Dietary Supplements 2017;15(2):207222.

9. Bicho NC, Leitao AE, Ramalho JC, Lidon. Identification of Chemical Clusters Discriminators of Roast Degree in Arabica and Robusta Coffee Beans. Eur J Food ResTechnol. 2011;(233): 303-311.

10. Arlt A, Sebens S, Krebs S, Geismann C, Grossmann M, Kruse ML, et al. Inhibition of the Nrf2 transcription factor by the alkaloid trigonelline renders pancreatic cancer cells more susceptible to apoptosis through decreased proteasomal gene expression and proteasome activity. Oncogene. 2013;32(40):4825-4835.

11. Huo L, Li CW, Huang TH, Lam YC, Xia $\mathrm{W}, \mathrm{Tu} \mathrm{C}$, et al. Activation of Keap1/Nrf2 signaling pathway by nuclear epidermal growth factor receptor in cancer cells. Am J Trans1 Res. 2014;6(6):649-663.

12. Ibrahim HK, Khalil HS, Langdon SP, Moult PR, Bown JL. NRF2 Regulates HER1 Signaling Pathway to Modulate the Sensitivity of Ovarian Cancer Cells to Lapatinib and Erlotinib. Oxidative Medicine and Cellular Longevity. 2017;(3):1-19.

13. Janzen, SO. Chemistry of Coffee. Germany : Cafea Gmb; 2010.

14. Muchtaridi, Yanuar A, Megantara S, Purnomo H. Kimia Medisinal : DasarDasar Dalam Perancangan Obat. Jakarta : Prenadamedia Group; 2018.

15. Allen WJ, \& Rizzo RC. Implementation of the Hungarian Algorithm to Account for Ligand Symmetry and Similarity in Structure-Based Design. J Chem Inf Model. 2014;(54):518-529.

16. Ismail RS, Ismail NS, Abuserii $\mathrm{S}$, El EDAA. Recent advances in 4-aminoquinazoline based scaffold derivatives targeting EGFR kinases as anticancer agents. Future Journal of Pharmaceutical Sciences. 2016;2(1):9-19

17. Nasab RR, Mansourian M, Hassanzadeh
F, Shahlaei M. Exploring the interaction between epidermal growth factor receptor tyrosine kinase and some of the synthesized inhibitors using combination of in-silico and in-vitro cytotoxicity methods. Res Pharm Sci. 2018;13(6):509-522.

18. Choowongkomon K, Sawatdichaikul O, Songtawee N, Limtrakul J. ReceptorBased Virtual Screening of EGFR Kinase Inhibitors from the NCI Diversity Database. Molecules. 2010;15(6):40414054

19. Sugunakala S, \& Selvaraj S. Identification Of Potential Inhibitors Of Epidermal Growth Factor Receptor Tyrosine Kinase By Virtual Screening And Docking Studies. Int J Pharm Sci Res. 2017;8(3):1264-74

20. Lipinski CA. Lead and Drug-Like Compounds: The Rule-of-Five Revolution. Drug Discov Today Technol. 2004;1(4):337-341.

21. Benet LZ, Hosey CM, Ursu O, Oprea TI. BDDCS, the Rule of 5 and drugability. Advanced Drug Delivery Reviews. 2016;(101):89-98.

22. Cheng F, Li W, Liu G, Tang Y: In Silico ADMET Prediction: Recent Advances, Current Challenges and Future Trends. Current Topics in Medicinal Chemistry. 2013;13(11):1273-1289.

23. Yaznadian M, Glynn SL, Wright JL, Hawi. A: Correlating Partitioning and Caco-2 Cell Permeability of Structurally Diverse Small Molecular Weight Compounds. Pharmaceutical Research. 2013;15(9):1490 - 1494.

24. Walmsley RM, \& Billinton N. How accurate is in vitro prediction of carcinogenicity?. British Journal of Pharmacology. 2011;162(6):1250-1258.

25. Nohmi T, Masumura K, ToyodaHokaiwado, N. Transgenic rat models for mutagenesis and carcinogenesis. Genes and Enviroment. 2017;39(11). 